\title{
Miejsca pamięci i mogiły wojskowe Wybrane zabytkowe nekropolie województwa łódzkiego z okresu I wojny światowej
}

\begin{abstract}
Streszczenie. Okolice Łodzi stały się w początkowej fazie I wojny światowej terenem krwawych walk toczonych w listopadzie i grudniu 1914 roku między wojskami niemieckimi i rosyjskimi, które określa się mianem Operacji łódzkiej. Pozostałością tych krwawych wydarzeń są cmentarze wojenne z mogiłami żołnierzy obu armii, które zostały wybudowane przez władze niemieckie w czasie I wojny światowej, oraz osobne grupy grobów znajdujące się w obrębie innych cmentarzy lub znajdujące się poza cmentarzami. Do dzisiaj na terenie województwa łódzkiego zachowało się $176 \mathrm{cmentarzy}$ i mogił z tego czasu. W okresie PRL groby te i cmentarze niszczały i popadały w zapomnienie. Sytuacja zmieniła się w latach 90 . XX wieku, gdy zainicjowane zostały działania renowacyjne i popularyzatorskie mające na celu przypomnienie Operacji łódzkiej. Zabytkowe groby i cmentarze otoczono opieką i stały się one ważnym elementem programów edukacyjnych, a także atrakcją turystyczną. W ramach projektów turystyczno-historycznych opracowano szlaki prowadzące śladami działań I wojny światowej i najciekawszych cmentarzy.
\end{abstract}

Słowa kluczowe: I wojna światowa, operacja łódzka, cmentarze wojenne, renowacja zabytkowych cmentarzy

kolice Łodzi stały się w początkowej fazie I wojny światowej terenem krwawych walk między wojskami niemieckimi i rosyjskimi, które toczyły się w listopadzie i grudniu 1914 roku. Zakończyły się one wycofaniem wojsk rosyjskich i zajęciem miasta przez wojska niemieckie, które okupowały je aż do końca I wojny światowej i odzyskania przez Polskę niepodległości ${ }^{1}$ Pozostałością

Operacja Łódzka. Zapomniany fakt I wojny światowej, red. Jolanta Daszyńska, Łódź 2011; Wielka Wojna o Ziemię Obiecaną: Operacja Łódzka 1914 = Lodzische Operation $1914=$ Lodzinskaâ Operaciâ 1914, I Konferencja na temat Operacji Łódzkiej 1914 w dniach 19-20 maja 2006 r. 
po tych wydarzeniach są porozrzucane po Ziemi Łódzkiej cmentarze wojskowe, na których spoczywają żołnierze niemieccy i rosyjscy, ale na grobach znajdziemy też wiele rodzimie brzmiących nazwisk - Polaków zmuszonych walczyć w obcych mundurach. Te szczególne pamiątki tragicznych wojennych wydarzeń prowokują do rozważań na temat historii, obyczajów, społeczeństwa, losów jednostek. Poświęcając uwagę datom i inskrypcjom na kamiennych płytach, przydrożnych tablicach, można w zarysie odtworzyć wydarzenia, jakie zaszły w najbliższej okolicy, również przekrój narodowościowy i wyznaniowy. Pamięć tych miejsc sukcesywnie zwracana jest historii. Za taką postawą ludzi stoi zwiększająca się świadomość wynikająca z potrzeby dbania o przeszłość, a także przesłanki moralne i empatia, wywołująca troskę o mogiły ludzi, którzy polegli z dala od swoich ojczyzn, domostw oraz rodzin.

Charakter tych miejsc ogranicza potrzebę stosowania bogatszych form dekoracyjnych. W większości groby tego rodzaju nie przedstawiają wartości artystycznych, nie reprezentują kierunków i form typowych dla XIX i pierwszych dekad XX wieku. Różnorodne konwencje artystyczne w postaci wyszukanych obelisków, sarkofagów, postumentów, stel, cippusów, aediculi czy alegorycznych rzeźb pełnoplastycznych zostały zredukowane do najprostszych przedstawień. Lakoniczny przekaz, nierzadko bezimiennym mogił, ogranicza się wyłącznie do daty śmierci. Do 1996 roku stan zachowania cmentarzy z okresu I wojny światowej określano jako zły².

Wydarzenia I wojny światowej to współcześnie historia odległa, a jej obraz został dodatkowo zapomniany przez kataklizm kolejnej wojny światowej. Jednak na mapie państw wciągniętych w zawieruchę wojenną pozostały materialne dowody, które jesteśmy zobowiązani kultywować i pielęgnować. W wielu miejscach - nazwach ulic, placów miast i miasteczek, płytach na elewacjach budynków, w pobliskich lasach i tych oddalonych, na skrajach dróg odnajdujemy ślady przeszłości, miejsca pamięci, które zaakcentowano w postaci inskrypcji czy też nagrobnego pomnika bądź obelisku.

Łódź otoczona jest pierścieniem cmentarzy i mogił wojennych z okresu Wielkiej Wojny ${ }^{3}$. W wykazie mogił i cmentarzy z lat 1914-1918 figuruje ich 176. Natomiast pojedynczych pochówków i zbiorowych mogił jest ponad tysiąc. Nie jest to liczba zamknięta, co jakiś czas odkrywane są nowe pochówki żołnierzy sprzed ponad 100 lat.

Cmentarze łączą walory artystyczne, historyczne, a także - lub może przede wszystkim - turystyczne. Nadmienić należy, iż rozważano stworzenie w okolicach

w Instytucie Historii Uniwersytetu Łódzkiego, red. Piotr Werner, Łódź 2006; Georgij Karpowicz Korolkow, Operacja łódzka 1914: najciekawsza batalia pierwszej wojny światowej, tłum. i oprac. Dominik Jednorowski, Oświęcim 2018.

Zabytkowe cmentarze 1996, s. 14.

Terminologia używana przed wybuchem II wojny światowej. 
Łodzi szlaku upamiętniającego wydarzenia Operacji łódzkiej. Projekt ten miał stanowić element realizacji ogólnopolskiego szlaku upamiętniającego działania z okresu I wojny światowej. Do 2014 roku na terenie 8 województw planowano zrealizować projekt historyczny pt. „Wschodnioeuropejski front I wojny światowej”. Przedsięwzięcie to miało na celu uatrakcyjnić poznawanie wiedzy historycznej oraz stać się atrakcją turystyczną na skalę porównywalną do francuskiego Verdun - gdzie stoczono jedną z największych bitew tej wojny ${ }^{4}$. Projekt realizowano pod hasłem „Muzeum w przestrzeni - wielkokulturowe korzenie regionu łódzkiego”. Obecnie materialnym dowodem istnienia szlaku są znaki informacyjne $z$ białymi napisami na brązowym tle, które informują o obiektach historycznych z lat 1914-1918. Nadrzędnym celem przedsięwzięcia było podniesienie turystycznej i rekreacyjnej atrakcyjności gmin biorących udział w programie poprzez wykorzystanie wydarzeń zapisanych w tradycji regionu jako Operacja łódzka lub Bitwa łódzka 5 .

Cmentarze, podobnie jak inne obiekty nieruchome, bez odpowiedniej opieki ulegają naturalnym procesom niszczenia, a czas zawsze działa na ich niekorzyść. Już w 1924 roku niemiecki dziennikarz relacjonował, że cmentarze stały się miejscem spotkań młodzieży, która nie zdaje sobie sprawy z takiego dziedzictwa. W okresie PRL likwidowano nekropolie niemieckie. Bywało również tak, że okoliczna ludność traktowała te miejsca jako składnice materiałów budowlanych. Dopiero w latach dziewięćdziesiątych XX wieku podjęto próby ratowania dawnych nekropolii. Dziś ta wiedza przybiera formy ochrony konserwatorskiej, a także podlega opiece inicjatyw społecznych w postaci komitetów oraz fundacji.

W północnej części województwa łódzkiego odnajdziemy zarówno cmentarze i mogiły wojenne, jak i wydzielone miejsca zbiorowych pochówków żołnierzy na cmentarzach różnych wyznań ${ }^{6}$. Wymieńmy tu cmentarze i mogiły wojenne w Wichrowie - na zachód od Łęczycy, Chruślinie, Rulicach, Domaniewicach - w kierunku północnym od Głowna. Dalej na wschód od Łowicza w granicach Bolimowskiego Parku Krajobrazowego - Budy Grabskie, Joachimów Mogiły, Bolimowska Wieś, Humin, Kęszyce czy w kierunku północnym od Zgierza - we wsi Dzierżązna.

To tylko wybrane miejsca pochówków. Zbiorowe mogiły odnajdziemy również na cmentarzach w Łęczycy, Ozorkowie, Piątku, Leźnicy Wielkiej, Giecznie, Łowiczu oraz Strykowie. Jak wcześniej zaznaczono, w całym województwie zinwentaryzowano 176 pochówków potwierdzonych dokumentacją. W opisywanych powyżej wydarzeniach poległy miliony osób różnych narodowości: Rosjanie, Niemcy,

\footnotetext{
4 Inicjatorem pomysłu był Michał Jagiełło, pracownik wydziału turystyki łódzkiego Urzędu Marszałkowskiego. Szlak turystyczny objął następujące województwa: podlaskie, warmińsko-mazurskie, mazowieckie, łódzkie, świętokrzyskie, lubelskie, małopolskie, podkarpackie.

5 www.koluszki.pl/muzeum-w-przestrzeni-wielokulturowe-korzenie-regionu-lodzkiego-etapi-opracowanie-koncepcji-i-wytyczenie-szlakow-turystycznych/ [dostęp: 29.05.2014].

6 Wśród nich: cmentarze rzymskokatolickie, ewangelickie oraz prawosławne.
} 
Austriacy, Węgrzy, Polacy, Ukraińcy, Słowacy, Czesi. Powstał cały ruch architektoniczny dotyczący projektów kaplic, nagrobków, krzyży. Podstawową zasadą zakładania cmentarzy była harmonia $\mathrm{z}$ najbliższym otoczeniem, walorami krajobrazu, rzeźbą terenu, która jako budulec wykorzystywała okoliczny materiał - drewno oraz kamień. Najczęściej miejsca pamięci lokowano w lesie lub na skraju terenów zalesionych. Jako przykłady takiej lokalizacji należy wymienić: Zgierz - Las Krogulec, Wiączyń Dolny, Poćwiardówkę, Pawlikowice, Wymysłów Piaski, Witkowice, Konstantynów - Rszew Legionowo.

Pojedyncze mogiły zazwyczaj upamiętniano kamieniem. Należy przy tym nadmienić, że prace przy wielu obiektach cmentarnych ograniczały się zaledwie do upamiętnienia terenu bitwy i jej ofiar. Innym popularnym zabiegiem oddania hołdu i pamięci poległym była tablica pamiątkowa. Czasami występują epitafia czy napisy w formie motta lub dewizy.

Aktualnie prowadzona waloryzacja obiektów opracowała kryteria ich wartości w skali trzypunktowej. Natomiast element turystyki - jego atrakcyjność, stan zachowania miejsc pamięci został zaprzęgnięty w wyliczenia procentowe. $\mathrm{W}$ ten sposób oszacowano walory atrakcyjności. Zdecydowaną większość cmentarzy zgrupowano w ocenie „średnia atrakcyjność” - 61,4\%. Bardzo wysoko sklasyfikowano 22,7\%, wysoko zaś zaledwie 6,8\% Jako mało atrakcyjne zakwalifikowano 9,1\% nekropolii ${ }^{7}$.

Nadrzędnym sposobem wartościowania jest kryterium oceny historycznej, artystycznej i naukowej, co jest równoznaczne z uznaniem obiektu za zabytek w świetle ustawy i wpisanie go do rejestru zabytków. Tym szczególnym obiektom należy poświęcić więcej uwagi zarówno historycznej, jak i turystycznej. Do tej grupy należą cmentarze: Rogów, gm. Józefów; Chruślin, gm. Bielawy, pow. łowicki; Bolimowska Wieś, gm. Bolimów, pow. skierniewicki; Humin Joachimów; Witkowice - Gałkówek, Jeżów ${ }^{8}$.

W miejscowości Dzierżązna, gm. Zgierz, znajduje się cmentarz usytuowany w rozwidleniu dróg polnych na planie trójkąta, w odległości $300 \mathrm{~m} \mathrm{w}$ kierunku południowym od drogi Biał-Dzierżązna. Założony został w 1915 roku dla żołnierzy niemieckich. Liczba pochowanych nie została ustalona. Zachowały się ślady dwóch kwater oraz kilka tablic betonowych żołnierzy poległych w 1914 roku.

W okolicach Rzgowa natrafimy na jeden z najciekawszych obiektów - cmentarz w miejscowości Gadka Stara. Miejsce pochówku rozciąga się wzdłuż ul. Czartoryskiego, na wzniesieniu. Cmentarz założono w 1915 roku na planie zbliżonym do sześciokąta. W centralnej części znajduje się pomnik wykonany z kamieni, ukształtowany jako kopiec, z tablicą pamiątkową wmurowaną w środkową część,

\footnotetext{
Gosik 2004, s. 89-101.

8 W artykule uwzględniono cmentarze, które zostały opracowane w rejestrze zabytków nieruchomych woj. łódzkiego do 31.12.2012 r.
} 
$167 \mid \begin{gathered}\text { TECHNE } \\ \text { TEX N H } \\ \text { SERIA NOWA }\end{gathered}$

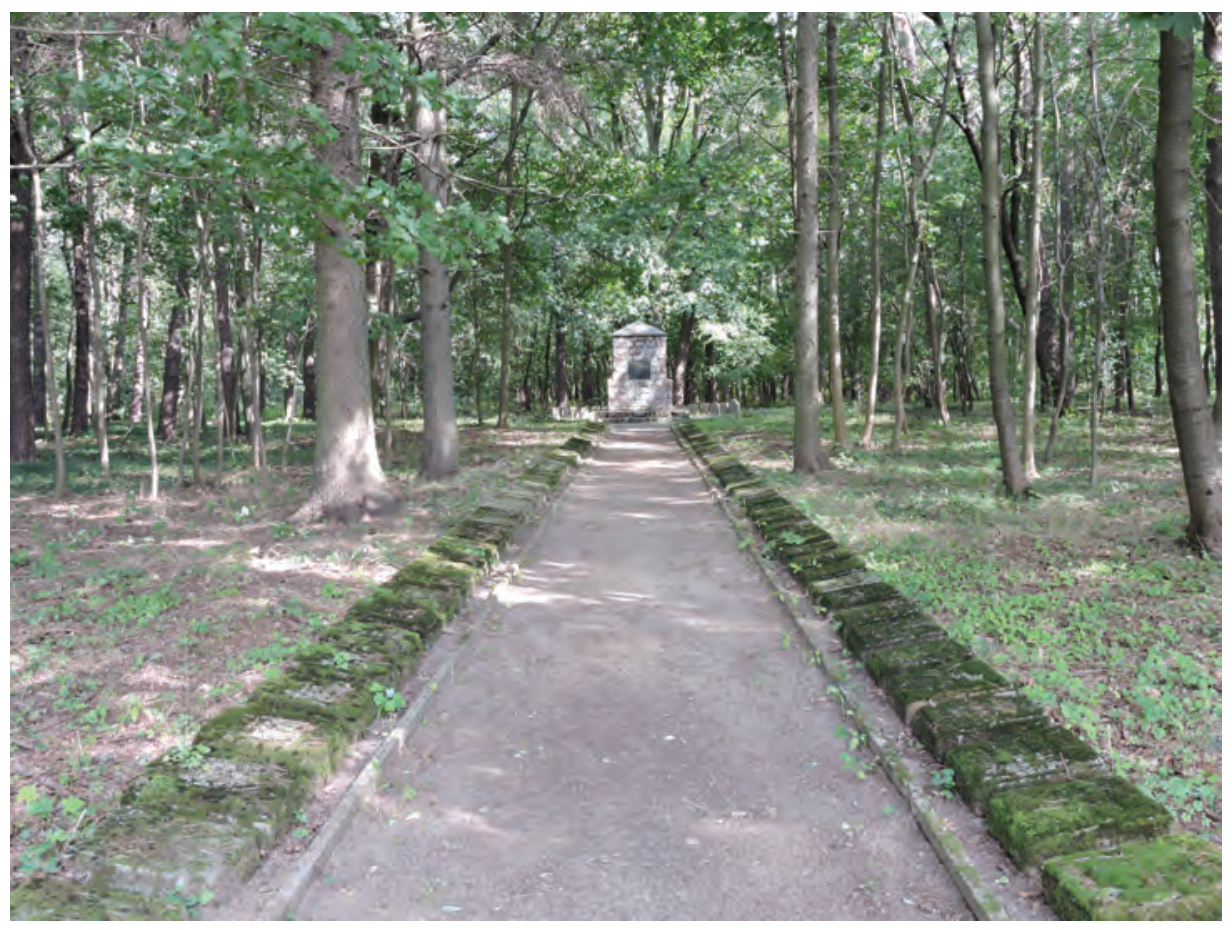

1. Poćwiardówka (gm. Brzeziny) - cmentarz wojskowy. Fot. K. Stefański, 2020

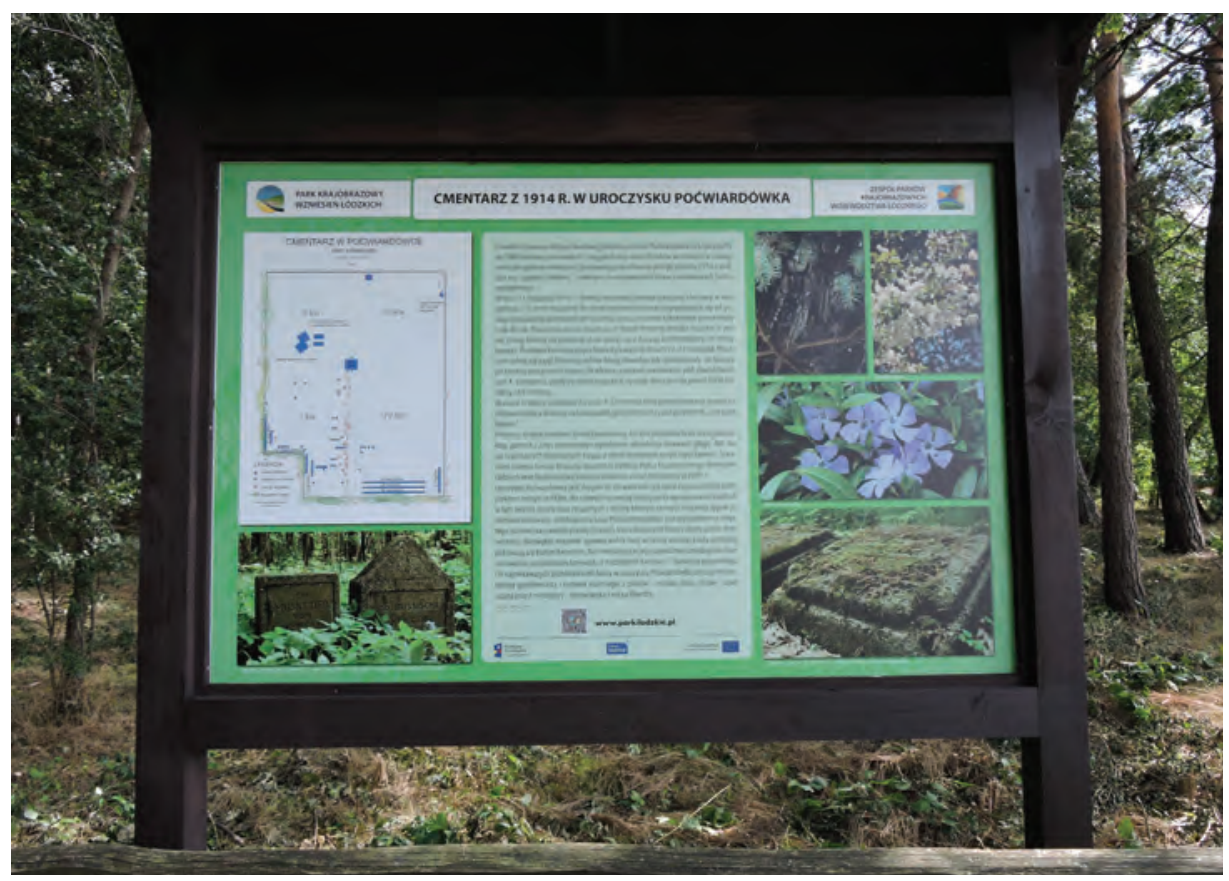

2. Poćwiardówka (gm. Brzeziny) - cmentarz wojskowy; tablica informacyjna. Fot. K. Stefański, 2020 


\section{TECHNE \\ T E X N H \\ SERIA NOWA}

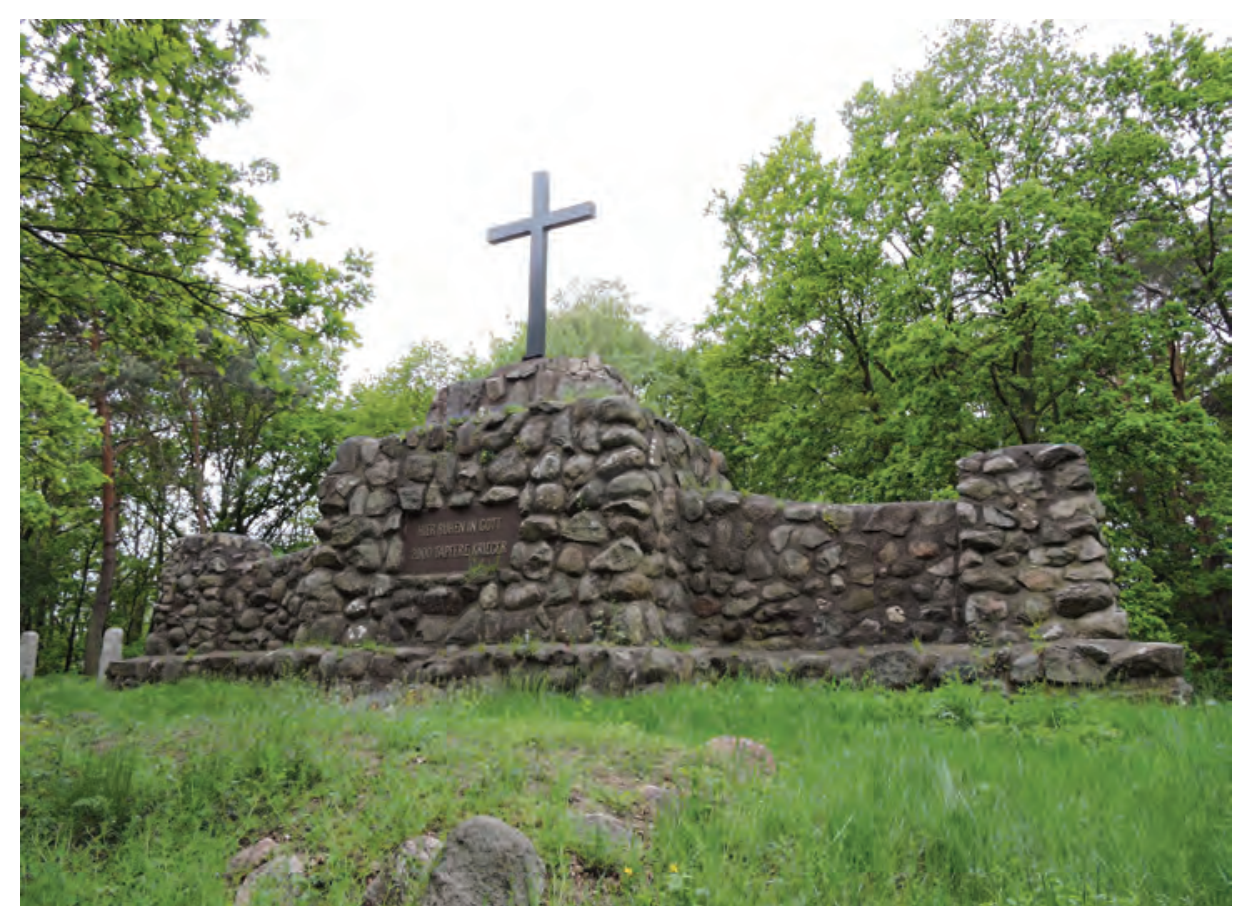

3. Gadka Stara (gm. Rzgów) - cmentarz wojskowy, pomnik od strony wschodniej Fot. K. Stefański, 2020

z inskrypcją: PRO PARTIA / HIER RUHEN IN GOTT 2000 TAPFERE KRIEGER. Zwieńczenie kamiennej kompozycji stanowi krzyż. Od pomnika rozchodzą się aleje główne biegnące w kierunku północ-południe i wschód-zachód. Aleje boczne rozkładają się pierścieniowato. Po przeciwnej stronie pomnika, symetrycznie po dwóch stronach alei wschód-zachód, usytuowano głazy z oznaczeniem formacji, z których pochodzili polegli. Za pomnikiem równolegle do linii głazów znajduje się pole ze zbiorową mogiłą niemieckich żołnierzy. Na cmentarzu są także groby rosyjskie9.

Gdy skierować się w stronę Pabianic, w odległości około $350 \mathrm{~m}$ w kierunku południowym od drogi Pawlikowice-Róża, w terenie leśnym można natrafić na inny cmentarz. Został on założony w 1914 roku na planie zbliżonym do prostokąta. Dokumentacja podaje, że pochowano w tym miejscu łącznie ok. 500 żołnierzy niemieckich i rosyjskich.

W okolicach Konstantynowa Łódzkiego, a dokładnie w miejscowości Rszew-Legionowo, w północno-zachodnich granicach, w terenie leśnym, znajduje się nieogrodzony cmentarz, na planie zbliżonym do kwadratu. Pochowano tu żołnierzy niemieckich, którzy polegli podczas bitwy o Łódź w listopadzie 1914 roku.

9 JABŁońsKi 1989, s. 53-57. 
$169 \mid \begin{gathered}\text { TECHNE } \\ \text { TEX N H } \\ \text { SERIA NOWA }\end{gathered}$

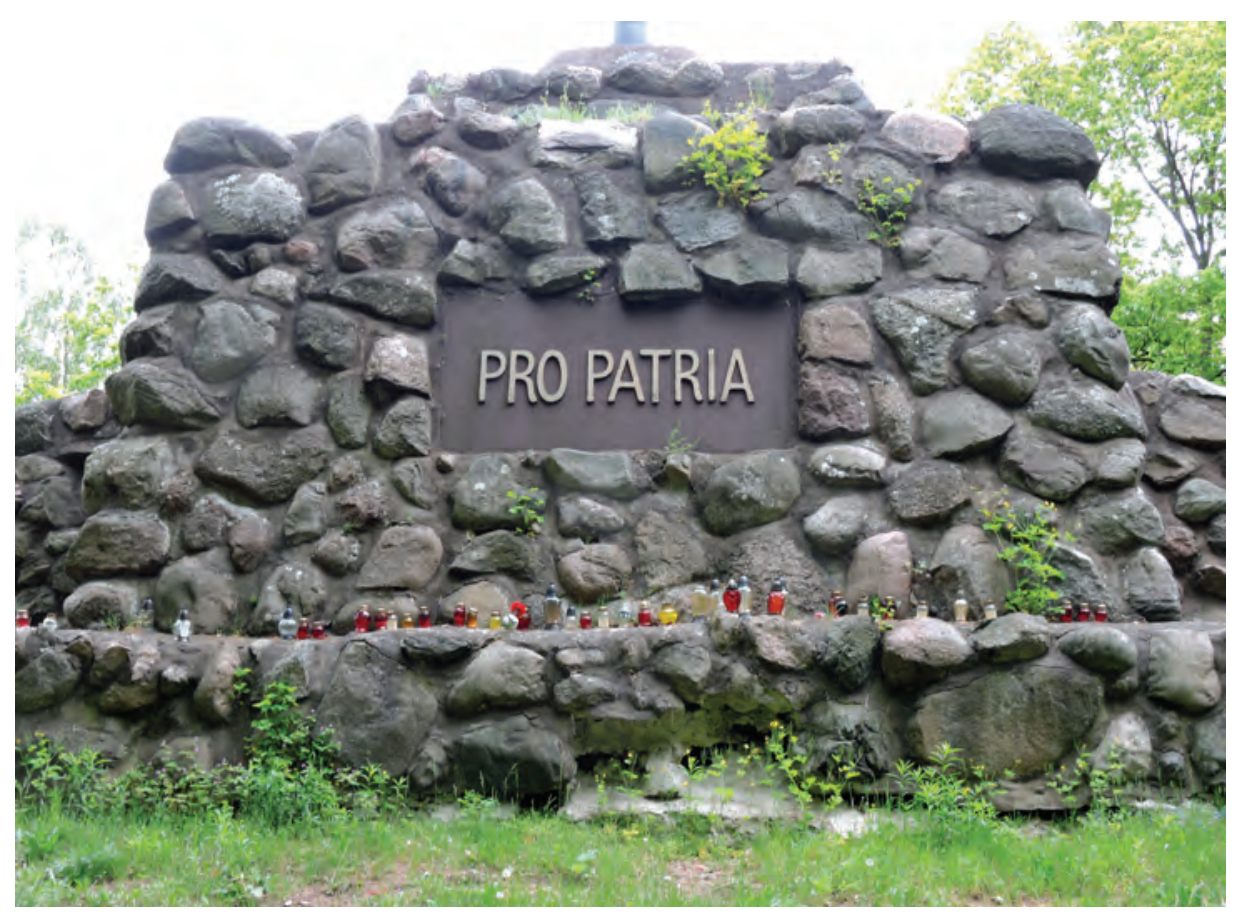

4. Gadka Stara (gm. Rzgów) - cmentarz wojskowy, tablica od strony zachodniej Fot. K. Stefański, 2020

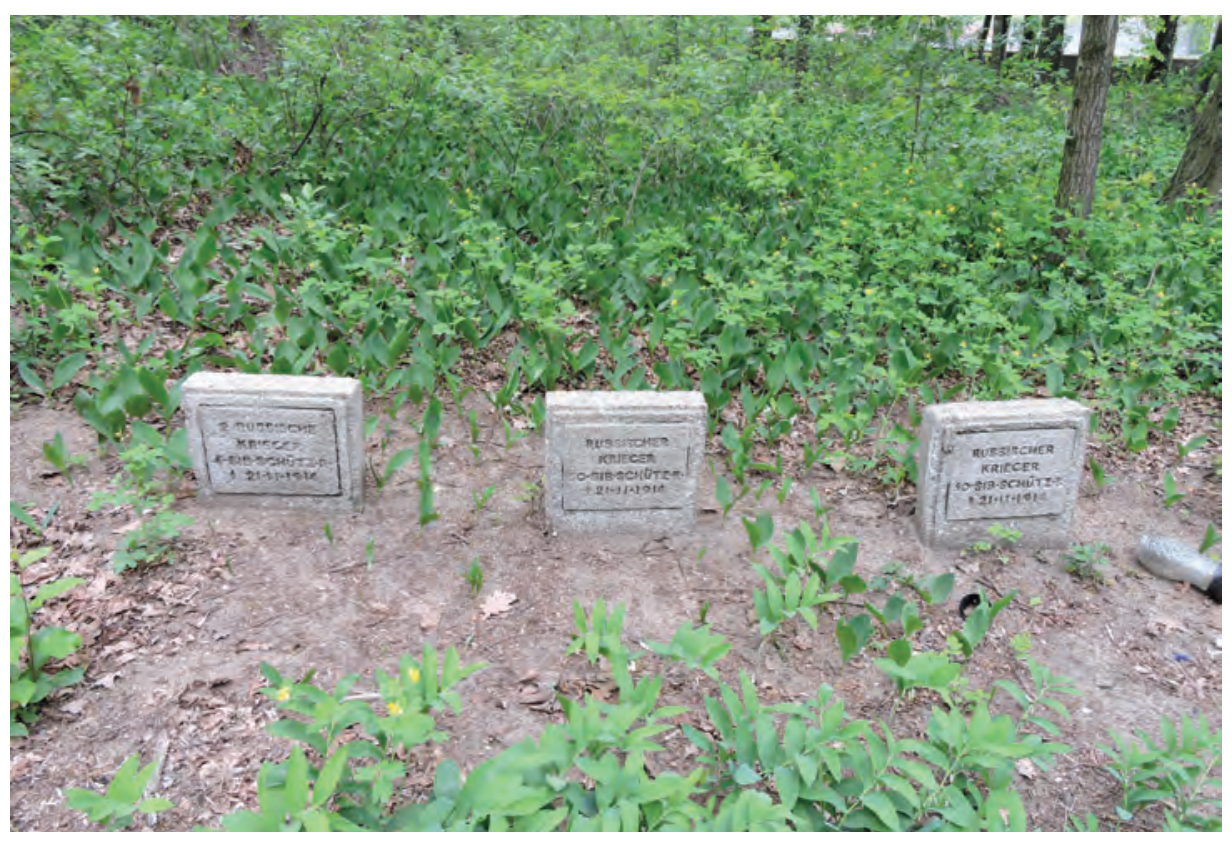

5. Gadka Stara (gm. Rzgów) - cmentarz wojskowy, groby żołnierzy rosyjskich Fot. K. Stefański, 2020 


\section{TECHNE \\ T E X N H \\ SERIA NOWA}

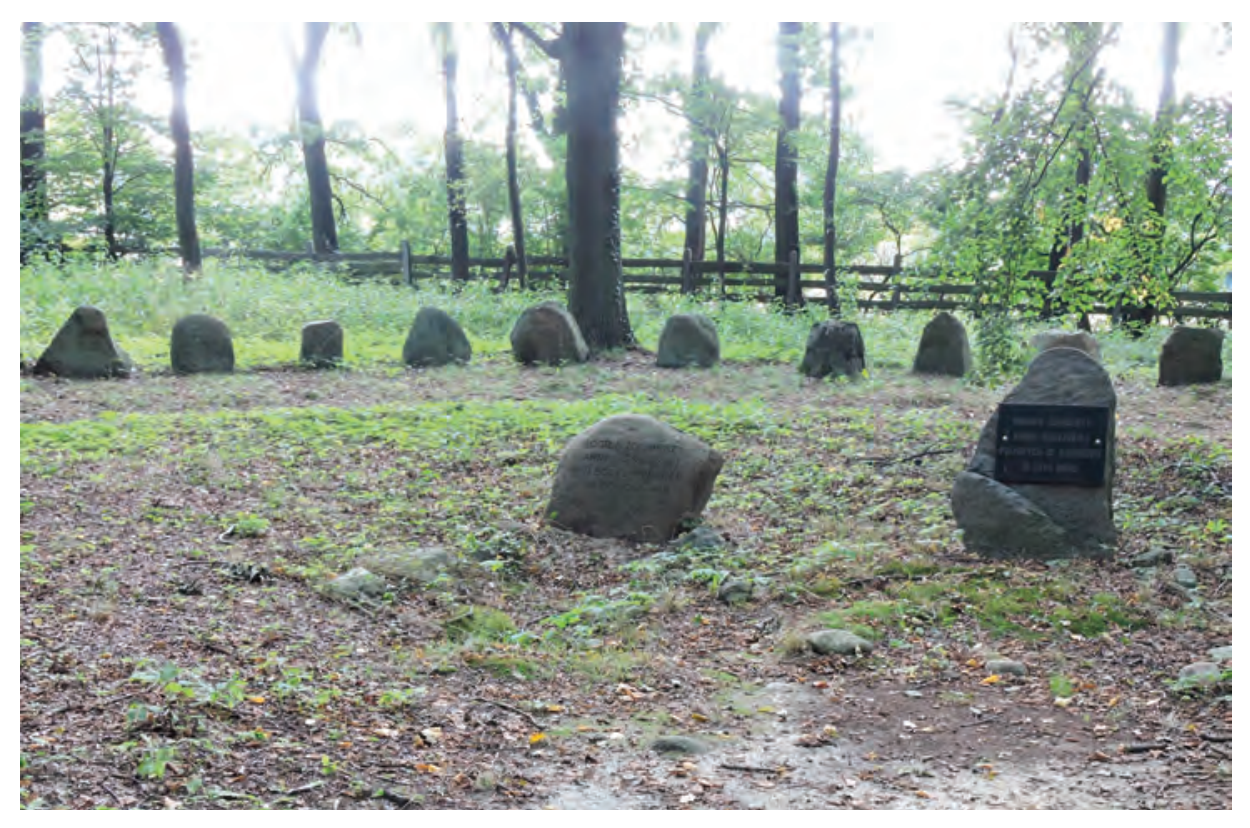

6. Wiączyń Dolny (gm. Nowosolna) - cmentarz wojskowy, groby żołnierzy rosyjskich

Fot. K. Stefański, 2020

Kształt części mogił jest czytelny. Oznaczono je betonowymi kubikami z nazwiskami poległych i przynależnością do formacji wojskowej.

W gminie Nowosolna, we wsi Wiączyń Dolny, na skraju lasu, w odległości ok. 500 m od głównej drogi Wiączyń-Nowosolna, znajduje się kolejna nekropolia sięgająca wydarzeń I wojny światowej. Cmentarz założono w latach 1914-1918. Jest on ogrodzony betonowymi słupami łączonymi poprzecznymi deskami. Teren przecinają dwie równoległe położone aleje w kierunku północ-południe. Arterie leśne porządkują pola i wydzielają kwatery żołnierzy niemieckich i rosyjskich. W krańcach każdej alei znajdują się krzyże wykonane z piaskowca - prawosławne po stronie rosyjskiej oraz łacińskie po niemieckiej. Na cokołach umieszczono nowe tablice inskrypcyjne. Miejsce pochówków zaznaczone jest głazami z informacjami imiennymi i stopniem wojskowym. Warto nadmienić, że pomniki z piaskowca ufundował łódzki przemysłowiec Karol Scheibler. Na uwagę zasługuje wydzielona mogiła w części wschodniej (niemieckiej) z listopada 1914 roku, z inskrypcją „Hans Voss” (sygn. E. Benndt, Łódź, ul. Felsztyńskiego 11), w kształcie krzyża wykonanego w kamieniu.

Kolejne miejsce pochówku poległych z lat 1914-1918 znajduje się w Zgierzu. Podlega ono zarządowi zgierskiego Urzędu Miejskiego i do 2006 roku pozostawało nieczynne. Nekropolia zlokalizowana jest w północno-zachodniej części miasta na terenie lasu Krogulec. Cmentarz urządzono w 1915 roku na planie zbliżonym do 


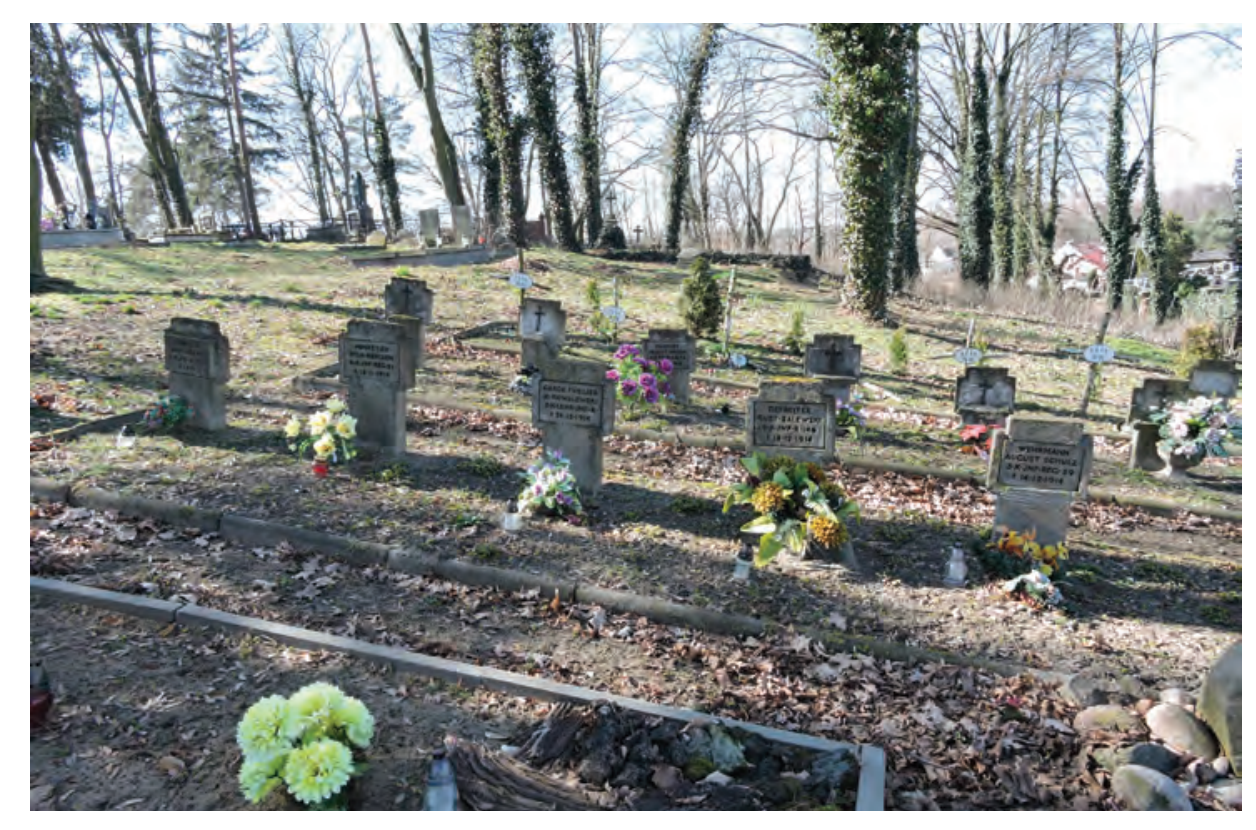

7. Ozorków - cmentarz ewangelicko-augsburski, kwatera z grobami żołnierzy poległych w czasie I wojny światowej. Fot. K. Stefański, 2020

prostokąta, z główną drogą leśną orientowaną na osi północ-południe. W części centralnej znajduje się pomnik - głaz narzutowy - upamiętniający nieokreśloną liczbę żołnierzy niemieckich i rosyjskich poległych między 18 listopada a 7 grudnia 1914 roku. Dwa mniejsze głazy obok głównego pomnika wskazują miejsce pochówku dwóch niemieckich oficerów piechoty poległych 18 listopada 1914 roku. Ponadto w lesie widoczne są ślady zbiorowych bezimiennych mogił ${ }^{10}$. W położonym na północny zachód Ozorkowie, na tamtejszym cmentarzu ewangelicko-augsburskim, zachowało się pole z ok. 20 grobami, w większości o formie niewielkich kamiennych krzyży, współcześnie uporządkowane. Zwracają na nim uwagę groby niemieckich żołnierzy o polskich nazwiskach.

Pośród innych imiennych i bezimiennych mogił, objętych opieką konserwatorską i widniejących w rejestrze zabytków, należy wymienić cmentarz w Bolimowskiej Wsi w powiecie skierniewickim, z kaplicą poświęconą poległym. Podążając w kierunku północnym, dojedziemy do miejscowości Humin. Tu trafimy również na kwatery grobowe poległych w latach 1914-1918. W granicach powiatu skierniewickiego znajdziemy jeszcze kilka istotnych miejsc pochówku. Dwa z nich położone są w kompleksie leśnym w miejscowości Joachimów Mogiły. Znajduje się tam monument dużej skali, w formie ziemnego kopca o kształcie okręgu obudowanego

10 Bortnowski 1969, s. 129-183; więcej: Zabytkowe cmentarze 1996, s. 67-68. 


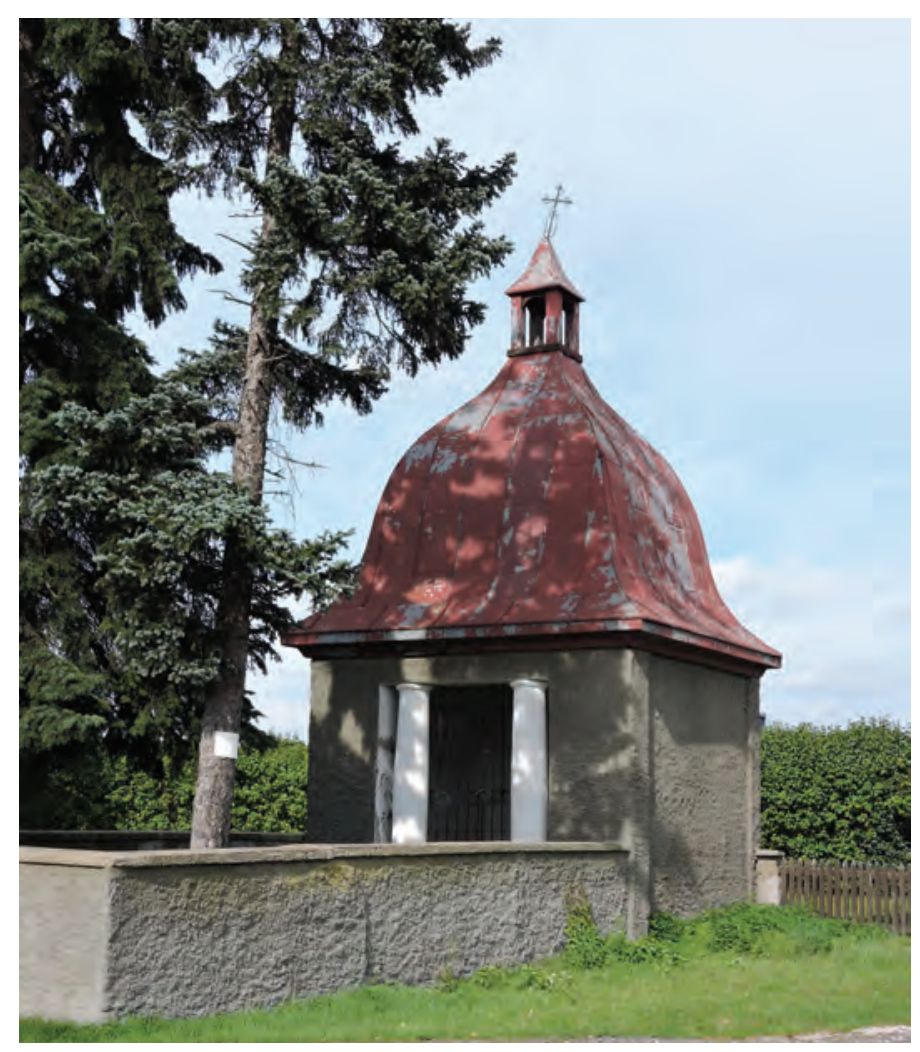

8. Bolimowska Wieś (gm. Bolimów) - kaplica ku czci żołnierzy poległych $w$ trakcie I wojny światowej. Fot. K. Stefański, 2020

ciosami z czerwonego piaskowca, z krzyżem w centrum. Na zewnątrz znajduje się drugi krąg z tego samego materiału, w postaci murku z ustawionymi nań krzyżami o formie zbliżonej do krzyży maltańskich. Między centralną częścią a drugim kręgiem znajdowała się pierwotnie fosa. W 1990 roku złożono tam również szczątki 2566 żołnierzy niemieckich poległych w czasie II wojny światowej, którzy zostali ekshumowani z Cmentarza Wojskowego na Powązkach w Warszawie, wzbogacając pomnik o tablice $\mathrm{z}$ nazwiskami żołnierzy ułożone $\mathrm{w}$ trzech kręgach ${ }^{11}$. W sąsiedztwie położony jest drugi cmentarz z grobami żołnierzy niemieckich i rosyjskich. Pamięć ofiarom przywraca tu biały drewniany krzyż z datami 1914-2014 na ramionach i tabliczką na przecięciu ramion z inskrypcją: „Pamięci 10 milionów ofiar I wojny światowej oraz żołnierzy Polaków wcielonych do zaborczych armii i zmuszonych do walki w obcych mundurach. W stulecie wybuchu Wielkiej Wojny". Niespełna piętnaście lat temu tylko skromna tabliczka informowała o miejscu żołnierzy nad rzeką Rawką. 
$173 \mid \begin{gathered}\text { TECHNE } \\ \text { TEX N H } \\ \text { SERIA NOWA }\end{gathered}$

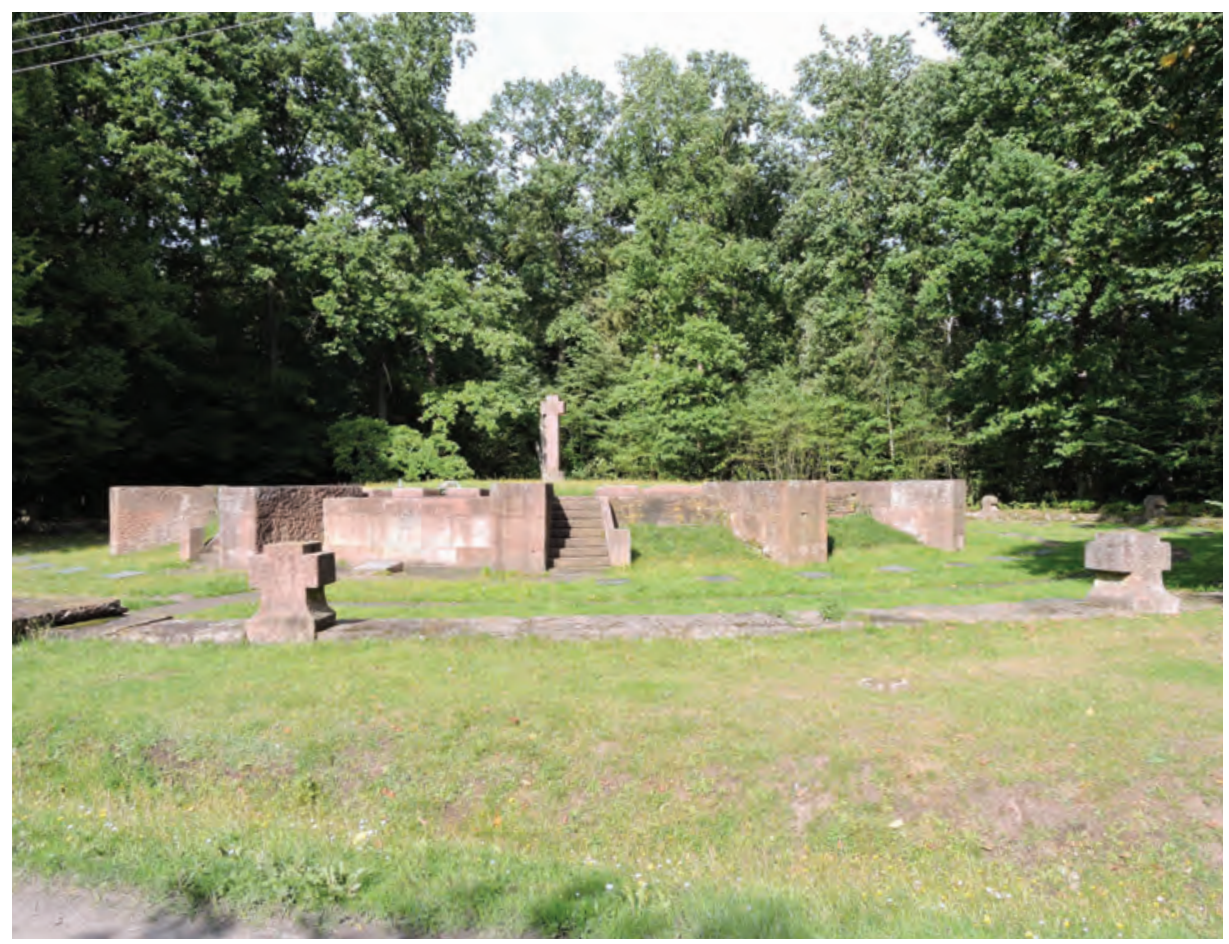

9. Joachimów Mogiły (gm. Bolimów) - widok ogólny pomnika. Fot. K. Stefański, 2020

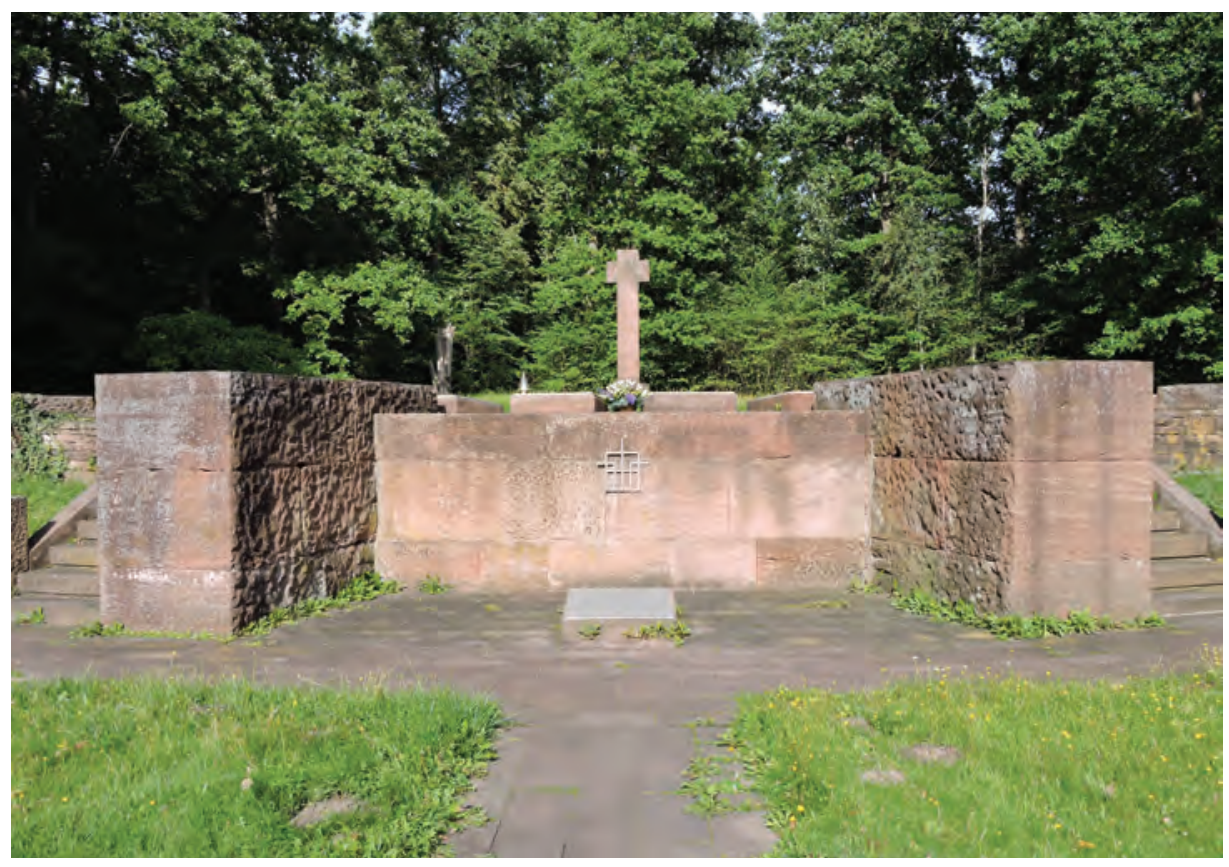

10. Joachimów Mogiły (gm. Bolimów) - widok frontowy pomnika. Fot. K. Stefański, 2020 


\section{TECHNE \\ T E X N H \\ SERIA NOWA

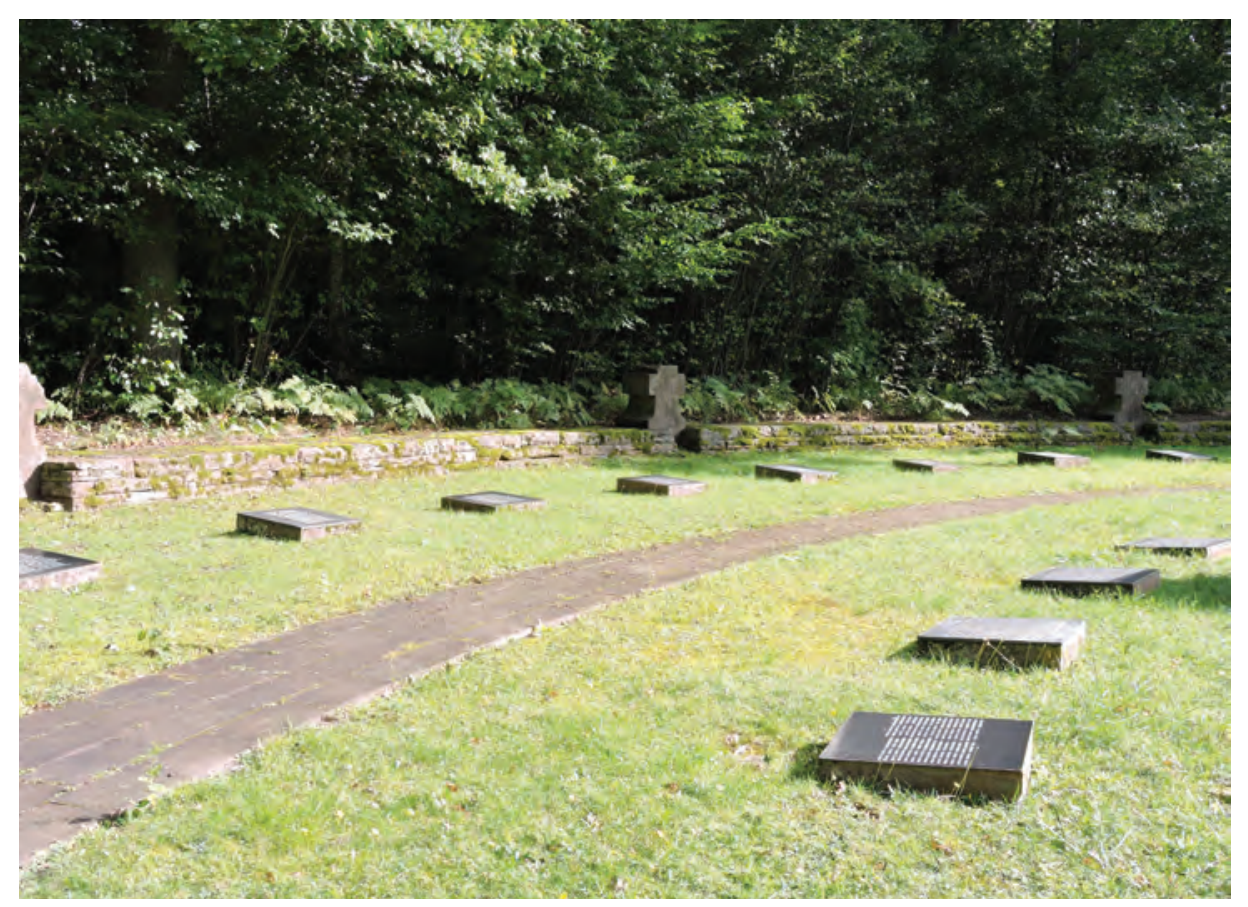

11. Joachimów Mogiły (gm. Bolimów) - tablice upamiętniające żołnierzy niemieckich z czasów II wojny światowej. Fot. K. Stefański, 2020

Przy drodze krajowej nr 72 znajduje się miejscowość Głuchów. Tu również odnajdziemy ślady Wielkiej Wojny - cmentarz z pochówkami niemieckimi. Bliżej granic Łodzi, w powiecie brzezińskim, w Witkowicach, trafimy na kolejne pozostałości historii. Jest to jeden $\mathrm{z}$ największych cmentarzy upamiętniających wydarzenia I wojny, położony na skraju lasu. Pochowano tu Rosjan i Niemców, którzy toczyli potyczki w okolicach Lasu Gałkowskiego w dniach 23-24 listopada 1914 roku. Podobne miejsca pamięci odnajdziemy w miejscowościach Józefów w gminie Rogów oraz Jeżów, natomiast w północnej części województwa łódzkiego w powiecie łowickim, w gminie Bielawy, znajduje się cmentarz żołnierzy rosyjskich.

W ramach projektu turystyczno-historycznego opracowano szlaki prowadzące śladami działań I wojny światowej i ich dziedzictwa. Powstało ich pięć:

I. Łódź - Zgierz - Szczawin - Swędów - Stryków - Poćwiardówka - Grzmiąca - Brzeziny.

II. Konstantynów Łódzki - Aleksandrów Łódzki - Zgierz - Rosanów - Ozorków - Dzierżązna - Gieczno.

III. Łódź - Mileszki - Wiączyń Dolny - Gałków - Borowa - Kaletnik - Żakowice - Felicjanów - Witkowice - Małczew. 
IV. Pabianice - Wymysłów - Pawlikowice - Rydzyny - Kalino - Gadka Stara.

V. Srock - Kiełczówka - Będków - Łazów - Wolbórz - Piotrków Trybunalski.

Szlaki turystyczne tworzone przez system cmentarzy i mogił wojskowych posiadają walory atrakcji związanych $\mathrm{z}$ tradycją, przeszłością regionu, pamięcią poległych. Odnosi się to do formy ochrony zabytku, który jest odpowiednio administracyjnie zarządzany oraz zadbany. Połączenie to tworzy świadomy układ zachodzący pomiędzy zabytkiem a odbiorcą. Wiedza ta rozwija się zarówno dzięki czynnikom

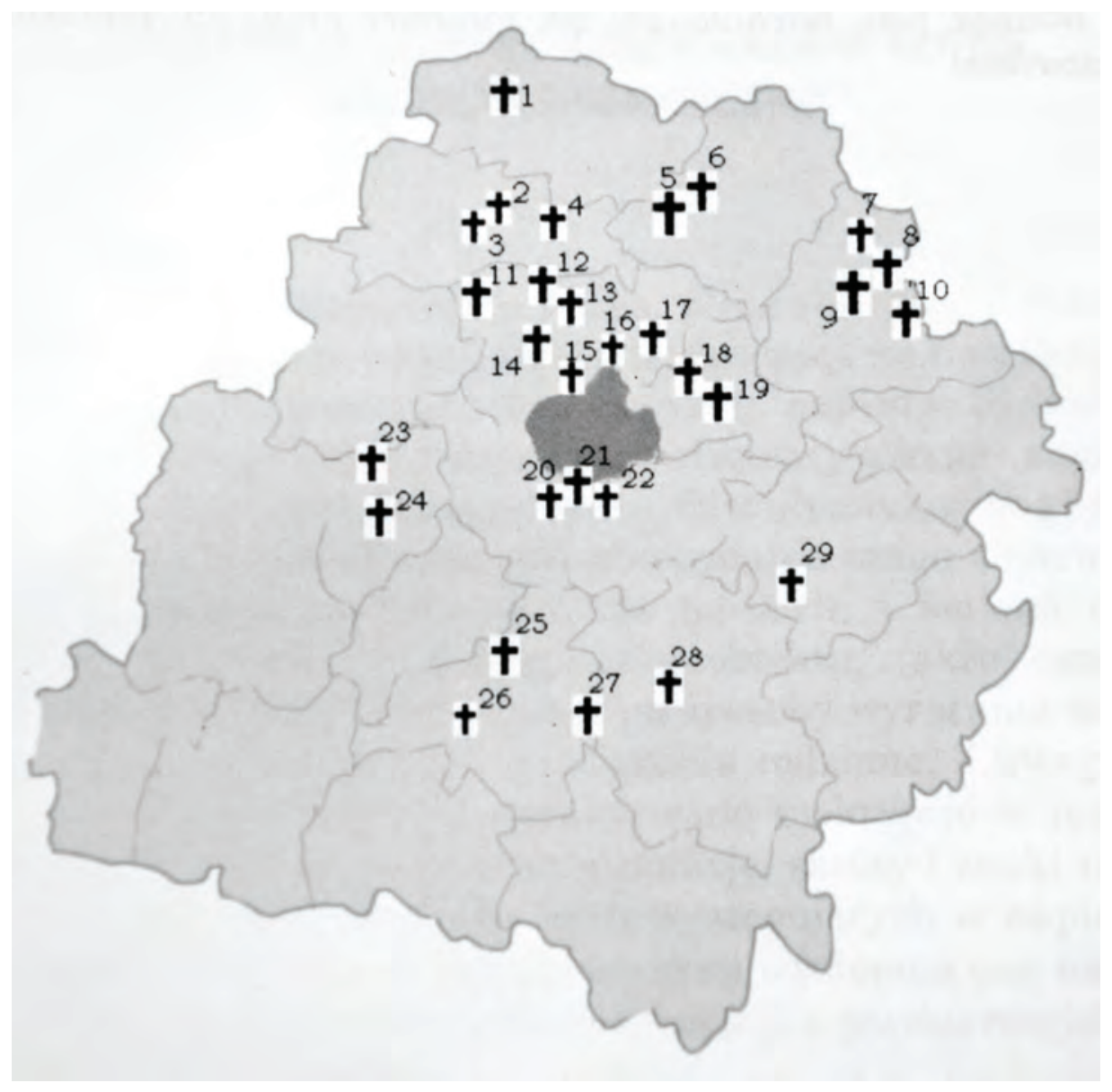

12. Wybrane zabytkowe nekropolie i mogiły wojskowe z okresu I wojny światowej na obszarze województwa łódzkiego. Źródło: Zabytkowe cmentarze i mogiły w Polsce. Województwo łódzkie, opracowanie własne.

Wykaz zgodny z numeracją: 1. Ostrowy, pow. kutnowski, 2. Łęczyca, 3. Wichrów, pow. łęczycki, 4. Piątek, pow. łęczycki, 5. Rulice, pow. łowicki, 6. Chruślin, pow. łowicki, 7. Kęszyce, pow. skierniewicki, 8. Humin, pow. skierniewicki, 9. Bolimów, pow. skierniewicki, 10. Joachimów Mogiły, Budy Stare, pow. skierniewicki, 11. Leźnica Wielka, pow. zgierski, 12. Ozorków, pow. zgierski, 13. Gieczno, pow. zgierski, 14. Dzierżązna, pow. zgierski, 15. Zgierz Krogulec, pow. zgierski, 16. Szczawin, Swędów, pow. zgierski, 17. Stryków, pow. zgierski, 18. Poćwiardówka, Janinów, pow. brzeziński, 19. Rogów-Józefów, pow. brzeziński, 20. Pawlikowice, pow. pabianicki, 21. Gadka Stara, pow. łódzki, 22. Kalino, pow. łódzki, 23. Szadek, Szadkowice, pow. zduńskowolski, 24. Zduńska Wola, 25. Zelów, pow. bełchatowski, 26. Szczerców Szubienice, pow. bełchatowski, 27. Barowa, pow. bełchatowski, 28. Piotrków Tryb., 29. Tomaszów Mazowiecki. Opracowanie własne Rafał Pakuła 
administracyjnymi, jak i społecznym. Podejmowane akcje porządkowania i inwentaryzacji terenów pozwalają uchronić miejsca zapomniane, zrujnowane przed postępującą dewastacją i zupełnym unicestwieniem. Większość obiektów cmentarnych i mogił posiada niekwestionowane wartości wskazywane w ustawie o ochronie zabytków. Celowo ochronie cmentarzy i pochówków przypisuje się wartość historyczną, która podkreśla, że obiekt jest dowodem istnienia określonych osób lub zdarzeń, posiada znaczenie dla kultury, a także wyraża się politycznie w kontekście historycznym. Z kolei wartość artystyczna charakteryzuje się tym, że obiekt wywołuje doznania estetyczne, z których również wynika znaczenie dla kultury.

Odpowiednie wyeksponowanie wydarzeń I wojny światowej na ziemi łódzkiej przy współdziałaniu organów państwowych, takich jak Urząd Konserwatorski, samorządy, a także działania non profit - społeczna forma ochrony i zaangażowania w ochronę miejsc i obiektów - pozwolą podejmować świadome decyzje, które promują zabytki, stanowią o ich atrakcyjności, zaś forma czynnego użytkowania nie pozostaje w sprzeczności z ochroną dziedzictwa kulturowego.

\section{Bibliografia}

\section{Opracowania}

BorTNOwSKi 1969 - Władysław Bortnowski, Ziemia łódzka w ogniu 1 VIII - 6 XII 1914 rok, Łódź 1969, s. 129-183.

Gosı 2004 - Blanka Gosik, Cmentarze z I wojny światowej jako walor antropogeniczny okolic Łodzi, „Turyzm” 2004, nr 14/2, s. 89-101.

JABŁoŃSKi 1989 - Cezary Jabłoński, Łódzkie cmentarze wielkiej bitwy XI-XII 1914 r., „Wędrownik" 1989 , z. 5/6, s. 53-57.

Zabytkowe cmentarze 1996 - Zabytkowe cmentarze i mogity w Polsce. Województwo Łódzkie, oprac. Anna Lewkowska, Wojciech Walczak, Warszawa 1996.

\section{Netografia}

https://koluszki.pl/muzeum-w-przestrzeni-wielokulturowe-korzenie-regionu-lodzkiego-etapi-opracowanie-koncepcji-i-wytyczenie-szlakow-turystycznych/ [dostęp: 29.05.2014].

https://pl.wikipedia.org/wiki/Joachim\%C3\%B3w-Mogi\%C5\%82y [dostęp: 29.05.2014]. 


\title{
Memorial sites and military graves Selected historic necropolises from the First World War in the Łódź Province
}

\begin{abstract}
$\ln$
the initial phase of World War I, the vicinity of Łódź became the scene of bloody battles between the German and Russian troops in November and December 1914, which are referred to as the "Łódź Operation". The remnants of these bloody events are the war cemeteries with the graves of soldiers from both armies, which were built by the German authorities during World War I, and separate groups of graves located within other cemeteries or outside cemeteries. To this day, 176 cemeteries and graves from that time have survived in the Lódź Province. During the PRL (Polish People Republic) period, these graves and the cemetery deteriorated and fell into oblivion. The situation has changed in the 1990s, when a renovation and popularization activity was initiated to recall the "Lódź Operation". Historic graves and cemeteries have been taken care of and have become an important element of educational programs as well as a tourist attraction. As part of the tourist and historical projects, routes leading to the traces of the First World War and the most interesting cemeteries were developed.
\end{abstract}

Keywords: It World War, Łódź Operation, military graves, renovation of historic cemeteries 